\title{
Daya Tarik Destinasi Wisata Pulau Kapo-Kapo di Kawasan Mandeh Kecamatan Koto XI Tarusan Kabupaten Pesisir Selatan
}

\author{
Nova Sullianti \\ Program Studi Geografi \\ Fakultas Ilmu Sosial, Universitas Negeri Padang \\ Email: novasulliantii28@gmail.com
}

\begin{abstract}
Abstrak
Penelitian ini bertujuan untuk mengetahui daya tarik destinasi wisata Pulau Kapo-Kapo di Kawasan Mandeh Kecamatan Koto XI Tarusan Kabupaten Pesisir Selatan. Daya tarik tersebut dapar dilihat dari (1) atraksi (2) aksesibilitas (3) amenitas (4) humanity. Jenis penelitian yang digunakan dalam penelitian ini adalah metode gabungan (Mixed Method). Sampel dan informan penelitian adalah pengelolah Pulau Kapo-Kapo, masyarakat sekitar Pulau Kapo-Kapo. Teknik pengumpulan data menggunakan observasi, kuesioner, wawancara, dan dokumentasi. Hasil penelitiannya yaitu (1)Atraksi wisata alam yang terdapat dapat di Pulau Kapo-Kapo dilihat dari kondisi pemandangan alam berupa hutan mangrove, pantai pasir putih, rekreasi perairannya seperti menyelam, memancing, dan lintas alam seperti tracking. (2)Aksesibilitas menuju Pulau Kapo-Kapo mudah dijangkau terlihat dari kondisi jalannya lurus dan beraspal dari pintu masuk, sedangkan jalan menuju Pulau Kapo-Kapo itu sendiri dapat dilihat langsung yaitunya dengan menggunakan akses laut. (3)Amenitas di Pulau Kapo-Kapo dapat dilihat dari 1 penginapan, 3 homestay, musholah, restoran, sumber air bersih, toilet, listrik dan tempat pembuangan sampah di Pulau Kapo-Kapo. (4) Humanity yang diberikan kepada pengunjung wisata seperti udara yang sejuk, kondisi lingkungan yang bersih, jauh dari kebisingan, pengunjung sudah merasa nyaman dengan kebersihan Pulau KapoKapo.
\end{abstract}

Kata Kunci : Daya tarik,Destinasi dan wisata

\begin{abstract}
This study aims to determine the attraction of Kapo-Kapo Island tourism destination in Mandeh District Koto XI Tarusan District Pesisir Selatan Regency. The attraction can be seen from (1) attractions (2) accessibility (3) amenitas (4) humanity. Type of research used in this research is Mixed Method (Mixed Method). Samples and research informants are Kapo-Kapo Island administrators, communities around Kapo-Kapo Island. Data collection techniques used observation, questionnaires, interviews, and documentation. The result of the research is (1) Natural attractions can be found on the island of Kapo-Kapo viewed from the natural scenery of mangrove forest, white sand beaches, recreational waters such as diving, fishing, and cross-country such as tracking. (2) Accessibility to Kapo-Kapo Island is easily visible from the straight and paved road conditions from the entrance, while the road to Kapo-Kapo Island itself can be seen directly by yaitunya using sea access. (3) Amenitas in KapoKapo Island can be seen from 1 inn, 3 homestay, musholah, restaurant, clean water source, toilet, electricity and landfill in Kapo-Kap Island. (4) Humanity given to tourist visitors such as cool air, clean environment conditions, away from the noise, visitors already feel comfortable with the cleanliness of Kapo-Kapo Island.
\end{abstract}

Keywords: Attraction, Destinations and tours 


\section{PENDAHULUAN}

Objek dan daya tarik wisata adalah suatu bentukan dan fasilitas yang berhubungan, yang dapat menarik minat wisatawan atau pengunjung untuk datang ke suatu daerah atau tempat tertentu. Daya tarik yang tidak atau belum dikembangkan merupakan sumber daya potensial dan belum dapat disebut wisata, sampai adanya suatu jenis pengembangan tertentu. Objek dan daya tarik wisata merupakan dasar bagi kepariwisataan. Tanpa adanya daya tarik di suatu daerah atau tempat tertentu kepariwisataan sulit untuk dikembangkan.

Dalam Undang-Undang No. 9 Tahun 1990 tentang kepariwisataan disebut bahwa objek dan daya tarik wisata adalah suatu yang menjadi sasaran wisata terdiri atas , objek dan daya tarik wisata ciptaan Tuhan Yang Maha Esa yang berwujud keadaan alam, flora, dan fauna. Serta daya tarik wisata hasil karya manusia yang berwujud museum, peninggalan purbaka, peningggalan sejarah, seni dan budaya, wisata agro, wisata buru, wisata petualangan alam, taman rekreasi, dan komplek hiburan.

Salah satu stakeholder pariwisata yang sangat mempunyai peran adalah wisatawan. Wisatawan adalah seseorang yang melakukan perjalanan wisata. Menurut Pitana (2005), dalam melakukan perjalanan wisata ataupun penetapan untuk melakukan kegiatan wisata seorang wisatawan banyak dipengaruhi oleh berbagai macam hal, baik itu secara internal maupun secara eksternal. Perjalanan wisata dilakukan oleh manusia untuk memenuhi kebutuhannya dalam mencari suatu pengalaman baru yan1g belum pernah mereka dapatkan sebelumnya. Faktor-faktor yang mempengaruhi seseorang untuk melakukan perjalanan wisata ini menjadi hal yang sangat menarik untuk dijadikan arahan dalam pengembangan daya tarik wisata (ODTW).

$\begin{array}{cccc}\text { Motif } & \text { atau } & \text { faktor } & \text { yang } \\ \text { mempengaruhi } & \text { para } & \text { wisatawan } & \text { dapat }\end{array}$ dijadikan acuan untuk para pelaku pariwisata dari mulai pemerintah, penyedia jasa wisata, pengelola tempat wisata dalam menentukan kebijakan-kebijakan maupun keputusan yang sesuai dengan keinginan dan kebutuhan dari wisatawan itu sendiri. Beberapa pendekatan yang dapat dilakukan yaitu melalui pendekatan market driven maupun product driven. Dalam sistem kepariwisataan, terdapat dua unsur pokok yang menentukan dalam pengembangan pariwisata. Kedua unsur tersebut adalah daya tarik destinasi dan pelayanan. Kedua unsur tersebut merupakan inti dari kegiatan pariwisata yang mendorong bagi seseorang (calon wisatawan) untuk melakukan kegiatan wisata.

Daya tarik destinasi dan kualitas pelayanan yang diberikan oleh para pelaku industri pariwisata kepada wisatawan disuatu destinasi wisata. Wisatawan akan tertarik dan bahkan dapat menghabiskan atau berlama-lama karena sesuatu hal atau kondisi lokasi destinasi wisata yang menarik dari destinasi wisata tersebut karena dengan adanya kenyamanan, fasilitas yang mendukung, aksesibilitas menuju lokasi wisata, berbagai bentuk aktivitas yang dapat dilakukan pada destinasi wisata, dan Humanity (kenyamanan yang didapat pada destinasi wisata) dari masyarakat yang berada di kawasan destinasi wisata.

Pulau Kapo-Kapo terletak di kawasan Mandeh, Kecamatan XI Koto 
Tarusan Kabupaten Pesisir Selatan, Sumatera Barat. Sekitar kurang lebih 40 menit dapat ditempuh melalui boat nelayan dari daerah Tarusan, Painan. Jangan harap akan mendapatkan dermaga yang bagus saat akan menuju ke Pulau tersebut yang ada malah jajaran hutan bakau yang akan dilalui sebelum menuju daratan karena kapal tidak bisa melewati perairan yang dangkal di area hutan bakau untuk memasuki Pulau KapoKapo dengan kapal nelayan.

Wisata Pulau Kapo-Kapo di kawasan Mandeh memiliki keindahan alam yang sangat indah dengan pantai yang begitu indah serta berbagai bentuk keindahan alam lainnya. Pulau Kapo-Kapo banyak sekali memiliki potensi alam yang dikelolah baik oleh pemerintah daerah setempat cukup berhasil. Tingkat kunjungan wisatawan yang mengunjungi objek wisata di Pulau KapoKapo cukup tinggi tercatat data dari kunjungan wisatawan yang berkunjung ke Pulau Kapo-Kapo dapat dikatakan meningkat dari tahun 2014 sampai tahun 2016. Di Pulau Kapo-Kapo seakan melihat dunia baru, pantai yang indah, sepi, dan damai. Pasir putih yang indah, koral di tepi pantai, air laut biru yang luas dipayungi langit biru yang indah, tidak heran jika dinamakan dengan hidden paradise (Surga Tersembunyi).

Pulau Kapo-Kapo yang begitu menarik sehingga kita ingin mengetahui komponen Supplay yang terdapat pada destinasi objek wisata yang ada di Pulau Kapo-Kapo seperti atraksi, aksesibilitas, aminitas dan Humaniti. Sehubungan dengan hal tersebut, maka penulis tertarik untuk mengakaji lebih lanjut mengenai "Daya Tarik Destinasi Wisata Pulau Kapo-Kapo DI Kawasan Mandeh Kecamatan Koto XI Tarusan Kabupaten Pesisir Selatan”.

\section{Metode Penelitian}

Metode yang digunakan dalam penelitian ini adalah metode gabungan (Mixed Method). Penelitian ini merupakan suatu langkah penelitian dengan menggabungkan dua bentuk penelitian yang telah ada sebelumnya yaitu penelitian kuantitatif dan penelitian kualitatif.

\section{Lokasi dan Waktu Penelitian}

Lokasi dari penelitian ini mencakup keseluruhan objek wisata yang berada di kawasan destinasi wisata Pulau Kapo-Kapo di Kecamaatan Koto XI Tarusan Kabupaten Pesisir Selatan.

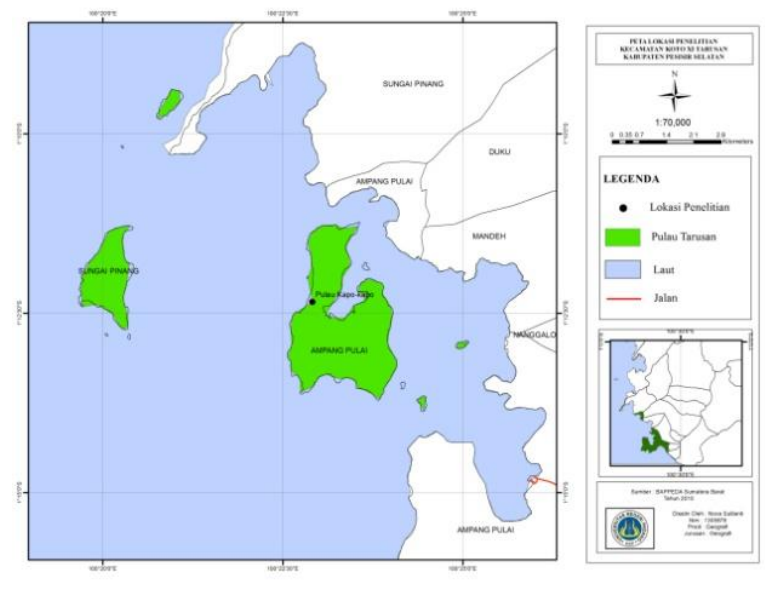


Peta Lokasi Penelitian

\section{Populasi dan Sampel}

1. Populasi

Populasi adalah keseluruhan subyek yang akan diteliti (Sulistyo-Basuki, 2006). Subjek penelitian yang diambil dari responden penelitian ini adalah orang yang dianggap banyak mengetahui informasi seputar tema penelitian. Subjek dalam penelitian ini adalah pengelola dan seluruh masyarakat di Pulau Kapo-Kapo

2. Sampel

Sampel adalah bagian tertentu dari keseluruhan subjek yang akan diteliti. Penelitian mixed method sering kali membutuhkan prosedur penyampelan metode campuran agar bisa secara simultan meningkatkan kualitas infrensi (validitas internal dan kepercayaan). Untuk mencapai hal ini, sering kali muncul kebutuhan akan dua jenis sampel: sampel probabilitas (untuk meningkatkan

generalizabilitas/transferabilitas) dan sampel bertujuan (untuk meningkatkan kualitas infrensi)

Teknik pengambilan sampel pada penelitian ini yaitu menggunakan cara purposive sampling yaitu pengambilan sampel berdasarkan tujuan, pada cara ini siapa yang akan diambil sebagai anggota sampel diserahkan pada pertimbangan pengumpul data yang berdasarkan atas pertimbangannya sesuai dengan maksud dan tujuan penelitian.

\section{Alat Penelitian dan Bahan}

a. Seperangkat komputer (Laptop), sistem type 32 bit Operating System dan perangkat lunak untuk memasukkan data, pengolahan dan keluaran data (ArcGIS 10.1 dan SPSS 16.0)

b. GPS (Global Positioning System)

c. Alat tulis

d. Alat dokumentasi

Bahan

a. Peta Administrasi

\section{Informan Penelitian}

Informan penelitian adalah orang yang diharapkan dapat memberikan informasi tentang situasi dan kondisi latar penelitian (Moleong, 2005). Penentuan informan yang akan diambil informasinya haruslah sesuai dengan karakteristik penelitian kualitatif, informan dalam penelitian ini pengelola, masyarakat sekitar Pulau Kapo-Kapo dan pengunjung wisata.

\section{Teknik Analisa Data}

1. Teknik analisa data kualitatif.

Analisa data yang digunakan untuk menganalisa data dalam penelitian ini adalah pengelolaan data, penyajian data, dan verivikasi data. Data dilapangan Model Aktifitas dalam analisis data kualitatif dilakukan secara interaktif dan berlangsung secara terus menerus sampai tuntas.

2.Reduksi data

Yaitu proses pemilihan, pemusatan, dan perhatian pada penyederhanaan, pengabsahan dan transfortasi data kasar yang muncul dari catatan-catatan tertulis dilapangan.

3. Interpretasi data

Interpretasi data yaitu data yang diperoleh dari mencari makna yang terkandung 
didalamnya kemudian dipaparkan dengan menggunakan katakata dan kalimat yang mudah dipahami.

4. Pengambilan keputusan

Dalam penelitian ini peneliti berusaha untuk mendapatkan informasi mengenai variabel yang diteliti. Jadi, data yang diperoleh dari lapangan yang telah dikumpulkan dan analisis ditarik kesimpulannya dan akhirnya akan menjadi hasil penelitian.

2. Teknik analisa data Kuantitatif

Dengan mempload semua titik-titik Amenitas yang ada di Pulau Kapo-Kapo ke dalam aplikasi Argcis.

\section{Teknik Pemeriksaan Keabsahan Data}

1. Perpanjangan Keikutsertaan

Dalam hal ini keikutsertaan peneliti sangat menentukan dalam pengumpulan data. Keikutsertaan tersebut bukan hanya dilakukan dalam waktu singkat tetapi memerlukan perpanjangan keikutsertaan peneliti dalam latar penelitian.

2. Penyajian data (Data Display)

Penyajian data merupakan sekumpulan informasi tersusun yang memberikan kemungkinan adanya penarikan, penyajian data berupa matrik, jaringan dan baganbagan yang dirancang guna menggabungkan informasi tersusun untuk menentukan kebenaran dalam penarikan kesimpulan.

3. Pengambilan kesimpulan (Verification)

Penarikan kesimpulan merupakan bagian dari konfigurasi yang utuh. Kesimpulan dilaksanakan selama penelitian, kesimpulan awal bersifat longgar dan akhirnya semakin rinci dan mengakar dengan kokoh. Apabila terjadi kesalahan data yang mengakibatkan kesimpulan tidak sesuai, maka dapat dilakukan proses ulang dengan melalui tahapan yang sama. Demi terjaminnya keakuratan data, maka peneliti akan melakukan keabsahan data. Dalam keabsahan data ini dilakukan proses tringulasi.

Tringulasi adalah membandingkan hasil wawancara dengan hasil pengamatan. Tringulasi dikelompokkan menjadi tiga jenis yaitu tringulasi waktu, tringulasi sumber dan tringulasi pengumpulan data. Dalam penelitian ini mengunakan metode triangulasi sumber yaitu: peneliti melakukan penelitian ulang serta melengkapi informasi apabila ada informasi yang tertinggal, Selanjutnya juga dilakukan pemeriksaan teman sejawat yang bertujuan untuk melihatkan kelebihan atau kekurangan hasil akhir sementara, hal ini dapat dilakukan dalam bentuk tanya jawab. Triangulasi yang dilakukan peneliti berupa member chek terhadap pertanyaan. Daftar pertanyaan yang dipakai ditinjau ulang sehingga pertanyaan penelitian sesuai dengan fokus penelitian. Triangulasi juga dapat dilakukan dengan audit trai yaitu melakukan audit atau pemeriksaan data oleh pihak luar, dari teman sejawat dan oleh dosen pembimbing.

\section{HASIL DAN PEMBAHASAN}

Kecamatan Koto XI Tarusan merupakan daerah paling utara dari kabupaten Pesisir Selatan. Secara geografis terletak pada $100^{\circ} 19^{\prime} 00^{\prime \prime} \mathrm{BT}$ $100^{\circ} 34^{\prime} 7^{\prime \prime} \mathrm{BT}$ dan $0^{\circ} 59^{\prime} 00^{\prime \prime} \mathrm{LS}$ $1^{\circ} 17^{\prime} 30^{\prime} \mathrm{LS}$, dengan luas daerah tercatat $425,63 \mathrm{Km}^{2}$ atau 7,0\%.

Jumlah penduduk di Kecamatan Koto XI Tarusan Tahun 2015 tercatat sekitar 48.590 jiwa, terdiri dari 24.085 jiwa laki- 
laki dan 24.505 jiwa perempuan, yang terdapat pada 11.505 rumah tangga. Dengan kepadatan penduduk sekitar 114.16 jiwa per $\mathrm{Km}^{2}$. Kepadatan penduduk tertinggi terdapat di Kenagarian Nanggalo dengan kepadatan sekitar 798 jiwa per $\mathrm{Km}^{2}$, sedangkan yang terendah terdapat di Kenagarian Taratak Sungai Lundang yaitu hanya 30,07 jiwa per $\mathrm{Km}^{2}$.

\section{Temuan Penelitian}

1. Kondisi Lokasi Penelitian

Pulau Kapo-Kapo yang terletak di Kawasan Mandeh Kecamatan Koto XI Tarusan adalah tempat yang peneliti pilih sebagai tempat penelitian karena tertarik meneliti mengenai daya tarik wisata di Pulau Kapo-Kapo. Daya tarik destinasi wisata dijadikan sebagai tempat wisata. Akses sebelum menuju Pulau tersebut melewati jalan menuju Carocok Tarusan, untuk sampai ke Carocok Tarusan akan ditemukan tiga jalur atau tiga persimpangan jalur ke kiri menuju objek wisata yang dinamakan Muaro Gadang, jalur tengah menuju lokasi wisata Pantai Batu Kalang dan jalur kanannya akan ditemukan Carocok tarusan, dan di Carocok Tarusan tersebut jalur menuju Pulau Kapo-Kapo dengan menggunakan boat atau kapal wisata yang telah disediakan, dibutuhkan waktu lebih kurang satu jam menit menuju Pulau KapoKapo.

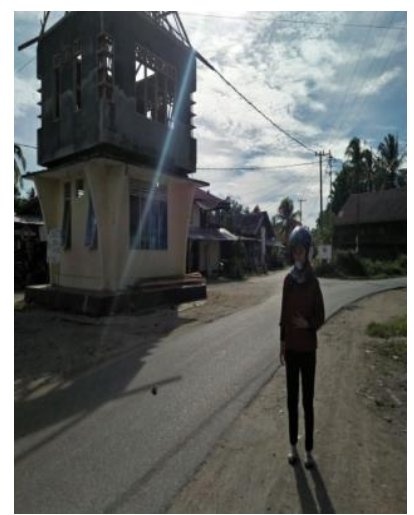

Gambar 1. kondisi jalan dari pintu masuk menuju Carocok Tarusan dokumentasi penelitian tanggal 14 November 2017

\section{Pengelolaan Pulau Kapo-Kapo}

Pengelolaan wisata Pulau Kapo-Kapo mulai dari perencanaan, pelaksanaan, dan pengawasannya tidak lepas dari dari partisipasi masyarakat. Tetapi diantara seluruh masyarakat yang berada di sekitaran Pulau Kapo-Kapo di tunjuklah stakeholder dalam mengelolah wisata Pulau Kapo-Kapo. Kerjasama stakeholder akan mematangkan proses perencanaan dan meminimalisir kemungkinan masalah dan konflik yang bisa muncul kemudian. Sebaliknya jika proses perencanaan dan pengelolaan tidak ada kerjasama antar stakeholder maka capaian pengelolaan juga tidak akan maksimal bahkan berpeluang menemui hambatan yang akan menggagalkan pencapaian tujuan pengelolaan kawasan itu sendiri. Tanpa kerjasama stakeholder maka pengelolaan akan menjadi parsial dan berjalan lambat serta tidak maksimal.

Selain pengelola masyarakat merupakan penggerak suatu kegiatan yang akan dilaksaknakan pada suatu daerah dengan tujuan yang sama, sama halnya dengan masyarakat yang tinggal di sekitaran Pulau Kapo-kapo kawasan Mandeh. Pemikiran 
keterlibatan dan partisipasi masyarakat yang berada di sekitaran Pulau Kapo-Kapo telah melahirkan sebuah destinasi wisata yaitu nya bentuk daya tarik wisata yang hadir dan diterima dikalangan masyarakat.

\section{Hasil Penelitian Daya tarik destinasi wisata Pulau Kapo-Kapo}

a. Atraksi

Atraksi wisata dapat diartikan segala sesuatu yang terdapat di daerah wisata yang dapat menarik wisatawan untuk berkunjung ke suatu daerah. Ciri khusus yang menjadi daya tarik wisata pengunjung dalam melakukan perjalanan untuk melakukan perjalanan wisata. Adapun jenis-jenis atraksi alam Menurut Damanik dan Weber (2006 : 2) diantaranya : pemandangan alam, keindahan pantai, vegetasi alam,rekreasi perairan, dan lintas alam.

Berdasarkan hasil wawancara dengan pengelola, wali nagari, dan msayarakat bahwasanya daya tarik Pulau Kapo-Kapo memiliki berbagai atraksi alam yang dapat dinikmati untuk menarik wisatawan berkunjung. Dapat dilihat dari kondisi pemandangan alam yang indah berupa hutan mangrove dijadikan tempat berfoto, udara sejuk, yang bagus untuk berwisata bersama teman dan keluarga, pantai pasir putih, rekreasi perairannya seperti menyelam, memancing, dan lintas alam seperti tracking. Di Pulau Kapo-Kapo juga terdapat atraksi wisata alam seperti berenang, menyelam, memancing, bermain pasir seperti yang dikatakan (Yulinda : 2007)

\section{Kondisi pemandangan alam}

Merupakan keindahan alam yang dapat dilihat dengan komponen mata dalam panca indra manusia. Pemandangan alam merupakan suatu hal yan perlu dijaga dan dilingdungi bertujuan untuk melindungi keindahan. Berdasarkan pengolahan data yang didapatkan dari lapangan mengenai kondisi pemandangan di Pulau Kapo-Kapo yaitu pemandangan alam yang indah, dengan pasir yang putih dan . hutan mangrove.

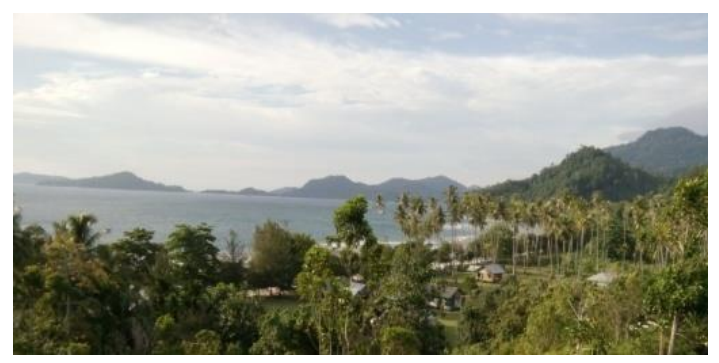

Gambar 2. Bentuk pemandangan alam di Pulau Kapo-Kapo

2. Rekreasi perairan

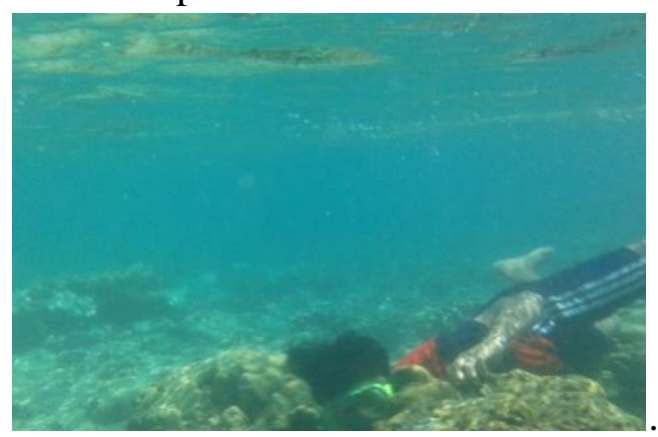

Gambar 3.Menyelam yang dilakukan di Pulau Kapo-Kapo

3. Vegetasi alam

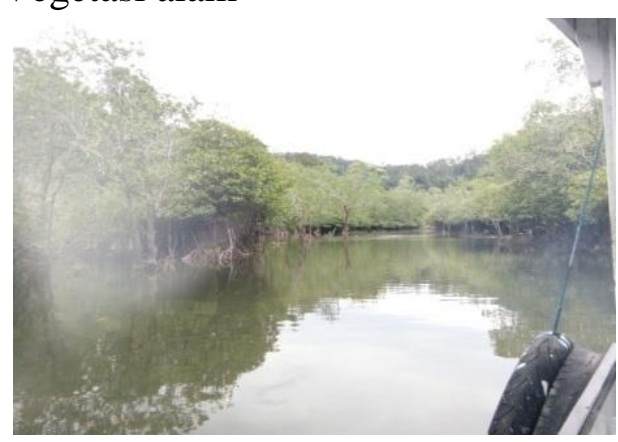

Gambar 4. Hutan mangrove di Pulau Kapo Kapo

4. Flora dan fauna 


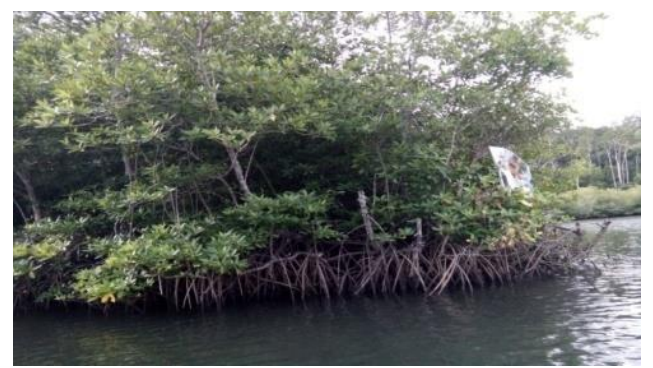

Gambar 5.Hutan mangrove di Pulau

Kapo-Kapo

5. Lintas Alam

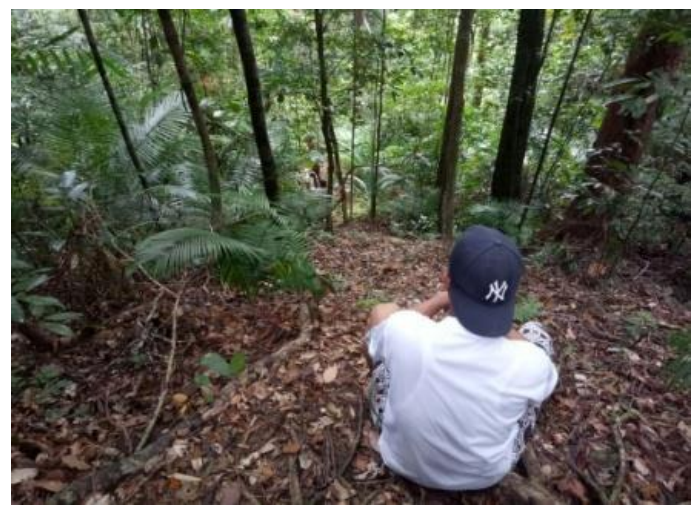

Gambar 6. Tracking di Pulau Kapo-Kapo dokumentasi 30 November 2017

\section{Aksesibilitas}

Aksesibilitas adalah kemudahan dalam mencapai daerah tujuan wisata baik secara jarak geografis atau kecepatan teknis,kondisi jalan, serta tersediannya sarana transportasi ke tempat tujuan tersebut (Triatmodjo, 1999).

Berdasarkan hasil wawancara dengan pengelola, wali nagari, dan pengunjung bahwasanya akses menuju Pulau Kapo-Kapo mudah dijangkau dengan kondisi jalan aspal yang baik dari pintu masuk, hingga pelabuhan Carocok Tarusan. Jarak tempuh dari Bandara Internasional MinangKabau untuk pengunjung yang berada dalam Provinsi maupun luar Provinsi menuju Pulau Kapo-Kapo lebih kurang 68 Km, sedangkan jarak tempuh dari pusat kota Padang menuju Pulau Kapo-Kapo sejauah 48 Km.
Transportasi yang digunakan dari Pusat kota Padang menuju Pulau Kapo-Kapo menggunakan mobil pribadi dan angkutan umum seperi bus atau travel, sedangkan transportasi yang digunakan dari dermaga Carocok Tarusan menuju menuju Pulau Kapo-Kapo menggunakan boat nelayan dan boat wisata. Waktu tempuh dari pusat kota menuju dermaga Carocok Tarusan 2 jam.dan dengan waktu tempuh dari dermaga Carocok Tarusan menuju lokasi wisata yaitunya Pulau Kapo-Kapo membutuhkan waktu selama lebih kurang 40 menit.Dan biaya yang dikeluarkan untuk sampai pada destinasi wisata Pulau Kapo-Kapo dari dermaga Carocok Tarusan dengan menggunakan boat nelayan atau boat wisata sebesar Rp. 600.000,- Rp. 700.000 sesuai dengan permintaan yang menyewakan transportasinya. Dari hasil penelitian bahwasanya akses menuju Pulau Kapo-Kapo sudah cukup baik karena mudah dijangkau dengan kondisi jalan, jarak tempuh dan transportasi.

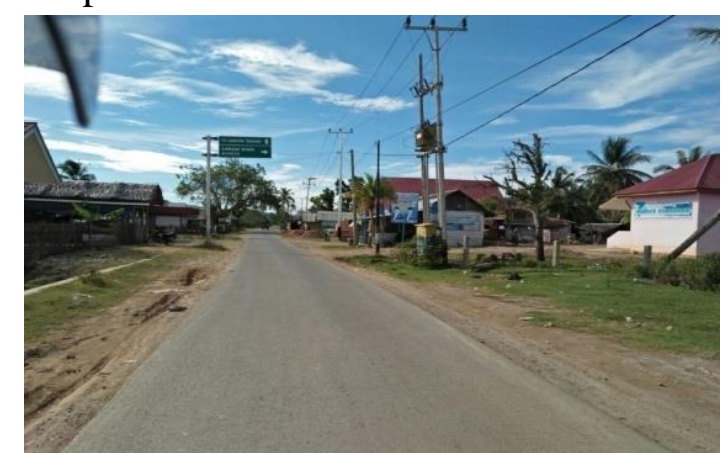

Gambar 7. Jalan menuju pelabuhan Carocok Tarusan 


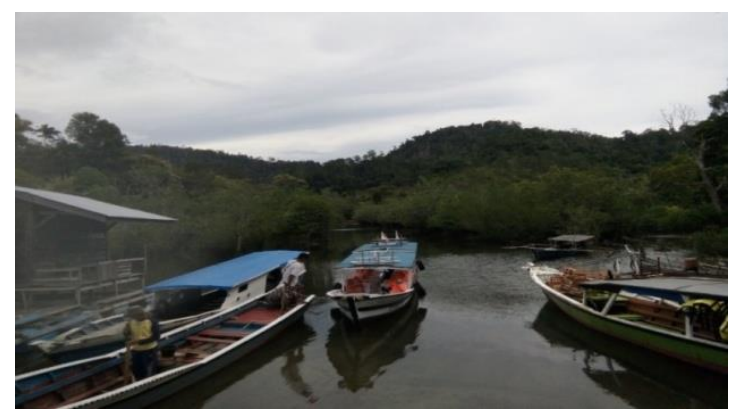

Gambar 8. Transportasi menuju Pulau Kapo-Kapo dengan menggunakan boat dan Kapal nelayan

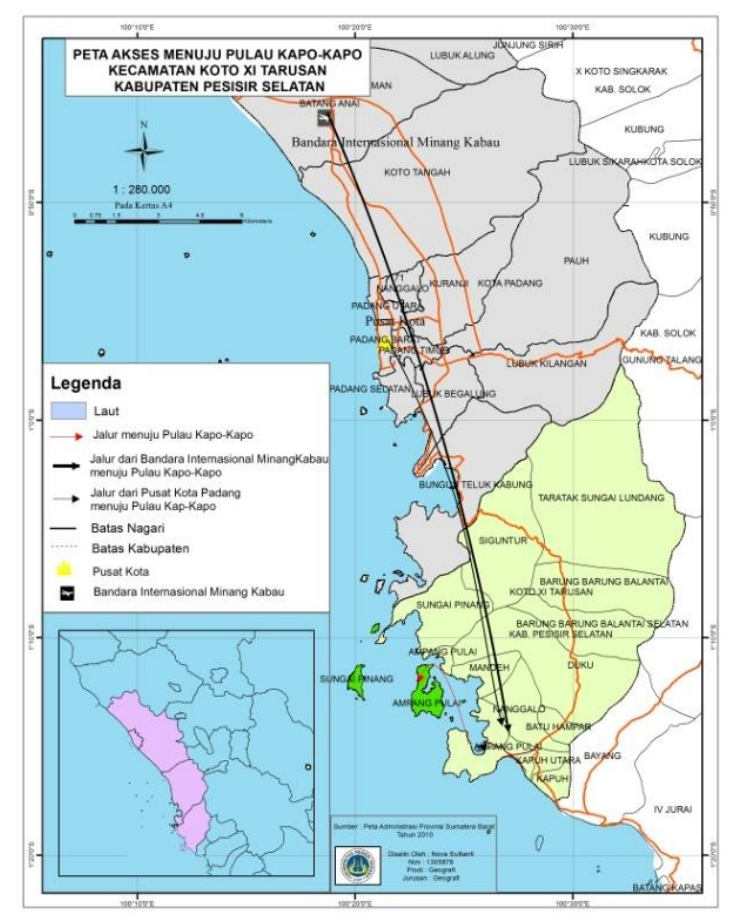

Peta Akses menuju Pulau Kapo-Kapo

\section{Amenitas}

Menurut Dirjen Pariwisata Indonesia Amenitas tersedianya fasilitas yaitu tempat penginapan, restoran, transportasi lokal yang memungkinkan wisatawan berpergian, alatalat komunikasi. Amenitas adalah fasilitas yang pendukung yang ditujukan untuk memberkan kenyamanan kepada wisatawan, fasilitas tersebut terdiri dari akomodasi, Amenitas di Pulau Kapo-Kapo dapat dilihat dari 1 penginapan yang dinamakan dengan cottage Kapo-Kapo terdapat 2 kamar dengan harga penginapan satu malam Rp. 800.000,/perkamar, dan 3 homestay yang disediakan masyarakat Pulau Kapo-Kapo dengan nama Homestay Monsu, Homestay incim dan Homestay Harimau dengan biaya penginapan permalam Rp.400.000,- satu kamar, tersedia 1 musholah dengan luas 10x8 M, rumah makan, pusat informasi wisata, took cendramata, pusat kesehatan, keamanan, sarana komunikasi, ketersediaan air bersih dan listrik

ketersediaan sebuah restoran cottage yang disediakan pengelolah dengan luas ketersediian sumber air bersih yang langsung di ambil dari mata air perbukitan dengan kondisi air yang bersih, jernih, dan sejuk. Selanjutnya ketersediaan tempat pembuangan sampah di Pulau Kapo-Kapo dilakukan dengan pembakaran. Dari penelitian dari pengelola bahwa fasilitas di Pulau Kapo-Kapo dapat di katakan cukup tersedia.

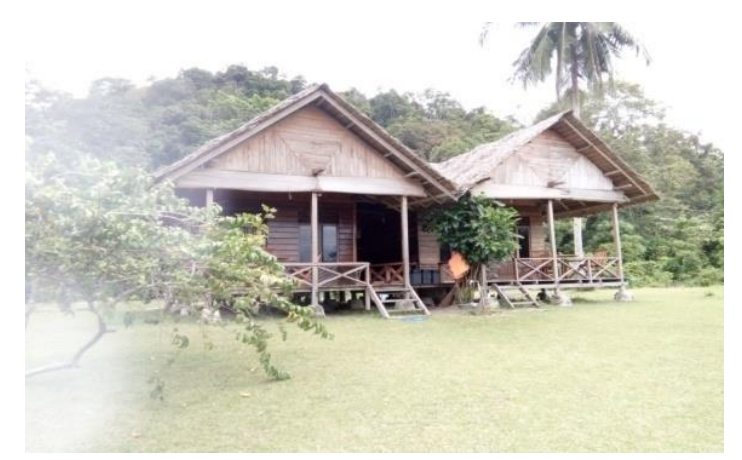

Gambar 9. Penginapan yang disedikan pengelolah di Pulau Kapo-Kapo 


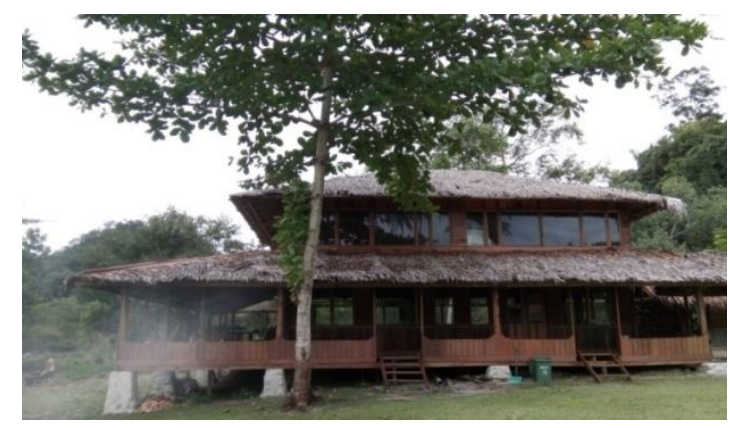

Gambar 10. Restoran di Pulau Kapo-Kapo dokumentasi 14 November 2017

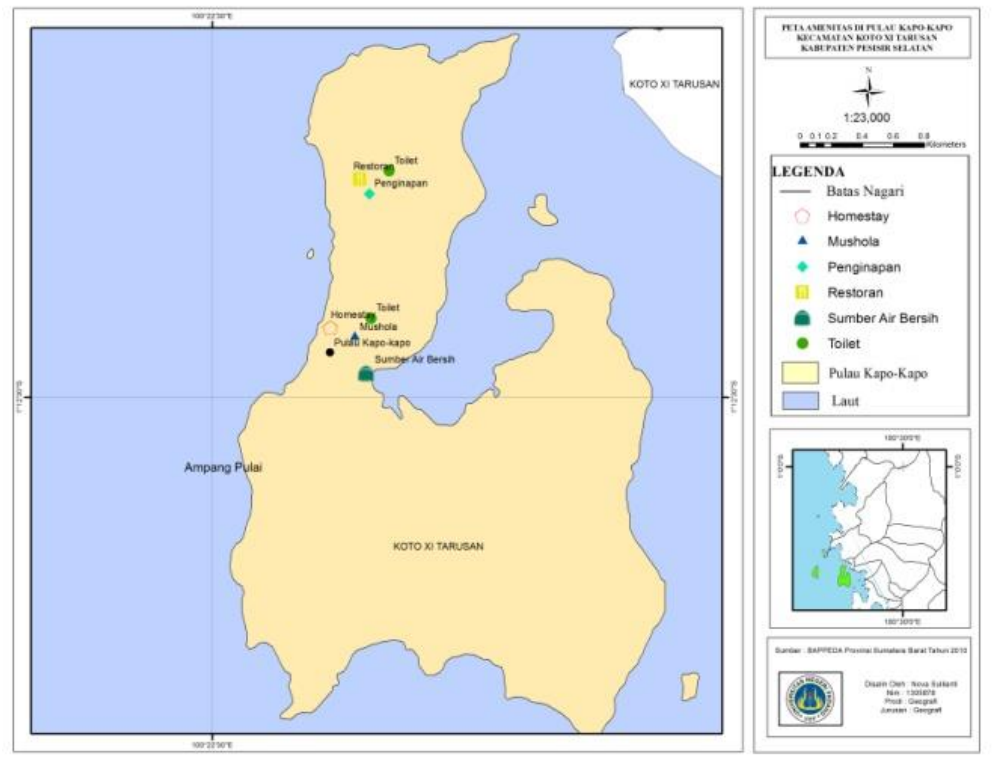

Peta Persebaran Amenitas Pulau Kapo-Kapo

\section{Humanity}

Kenyamanan dan keamanan bagi wisatawan merupakan salah satu faktor yang menentukan keputusan untuk melakukan suatu perjalanan ke suatu destinasi pariwisata. Kenyamanan dan keamanan menjadi kondisi yang sangat penting dalam industri pariwisata. Aspek tersebut pada dua dekade terakhir telah menjadi isu yang semakin besar dan mempunyai dampak yang sangat besar terhadap keberlangsungan aktivitas perjalanan dan pariwisata.

Kenyamanan sangat penting pada suatu objek wisata karena dengan kenyamanan dapat menarik wisatawan untuk berkunjung ke Pulau Kapo-Kapo dan berdiam lebih lama. Kenyamanan yang diberikan kepada pengunjung wisata seperti udara yang sejuk, tempatnya bersih, jauh dari kebisingan, pengunjung sudah merasa nyaman dengan dukungan masyarakat yang memberikan kenyamanan seperti pelayanan kepada pengunjung, dengan menyediakan beberapa pihak keamanan yang memang ditugaskan untuk keamanan pengunjung dalam mengunjungi Pulau Kapo-Kapo. Dari hasil wawancara dari beberapa pengunjung diperoleh informasi bahwa pengunjung sudah merasa nyaman dengan dukungan masyarakat yang memberikan kenyamanan serta keaman an di Pulau Kapo-Kapo. 


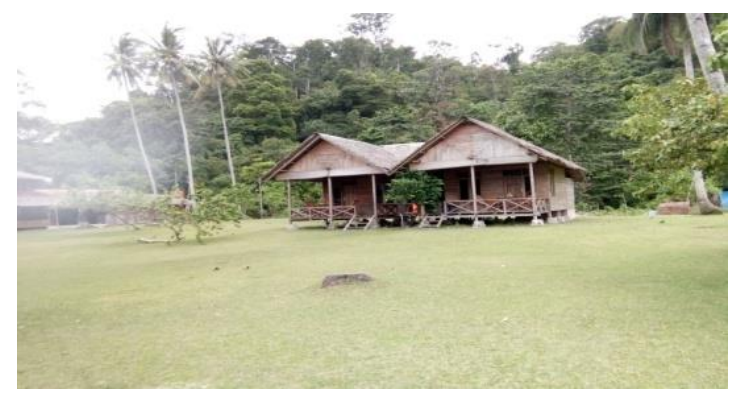

Gambar 10. Kebersihan di Pulau KapoKapo

\section{PENUTUP}

\section{Kesimpulan}

1. Atraksi wisata

Atraksi wisata alam yang terdapat dapat di Pulau Kapo-Kapo Dapat dilihat dari kondisi pemandangan alam yang indah berupa hutan mangrove dijadikan tempat berfoto,udara sejuk,yang bagus untuk berwisata bersama teman dan keluarga, pantai pasir putih, rekreasi perairannya seperti menyelam, memancing, dan lintas alam seperti tracking.

2. Aksesibilitas

Akses menuju Pulau Kapo-Kapo mudah dijangkau dari Bandara Internasional MinangKabau sejauah $68 \mathrm{Km}$ melewati jalan provinsi menuju Tarusan, dari Tarusan menuju carocok tarusan sejauah $5 \mathrm{Km}$ melalui jalan kabupaten, yang tergolong baik, dikategorikan jenis jalan lokal hanya saja pada titik tertentu ada jalan yang rusak sepanjang $3 \mathrm{M}$, bukan berlobang tetapi sedikit retak, sedangkan jalan menuju Pulau Kapo-Kapo itu sendiri dapat dilihat langsung yaitu dengan menggunakan akses laut sejauah $7 \mathrm{Km}$.

3. Amenitas

Amenitas di Pulau Kapo-Kapo dapat dilihat dari 1 penginapan yang, 3 homestay yang disediakan masyarakat, sebuah musholah dengan luas 10x8 M, ketersediaan restoran ketersediian sumber air bersih yang langsung di ambil dari mata air perbukitan, ketersediaan toilet, listrik dan ketersediaan tempat pembuangan sampah di Pulau KapoKapo dilakukan dengan pembakaran.

\section{Humanity}

Untuk aspek kenyamanan yang terdapat di Pulau Kapo-Kapo berdasarkan wawancara dari para pengunjung wisata dapat diketahui bahwa kenyamanan yang diberikan oleh masyarakat setempat telagh tergolong baik. Pelayanan kenyamanan yang disuguhkan oleh masyarakat kepada pengunjung seperti kondisi lingkungan yang bersih, dan jauh dari kebisingan.

\section{SARAN}

1. Diharapkan pengelolah dan masyarakat lebih mengetahui bentuk daya tarik wisata dimiliki Pulau Kapo-Kapo yang dapat dijadikan sebagai objek wisata, hal ini bertujuan agar destinasi wisata Pulau KapoKapo lebih dikenal. Karena apabila bentuk daya tarik wisata Pulau Kapo-Kapo tidak dikembangkan, maka akan menyebabkan Wisata Pulau Kapo-Kapo tidak dikenal lagi sebagai kawasasn Wisata.

2. Sebaiknya masyarakat melakukan halhal yang dapat meningkatkan daya tarik yang dimiliki wisata Pulau Kapo-Kapo, karena apabila dilihat selama ini kegiatan yang dilakukan terhadap pada wisata Pulau Kapo-Kapo terbilang monoton tanpa ada pergerakan dan aktivitas baru dalam ragka untuk meningkatkan daya tarik kunjungan wisata.

\section{DAFTAR PUSTAKA}


Basuki, Sulistyo. 2006. Metode Penelitian. Jakarta: Wedatama Widya Sastra.

Creswell W, Jhon. 2013. “ Research Design: Pendekatan Kualitatif kuantitatif dan mixed". Pustaka Pelajar.

Damanik, Janianton dan Wever, Helmut. 2006. Perencanaan Ekowisata Dari Teori ke Aplikasi. Yogyakarta : PUSPAR UGM dan ANDI

Moleong, lexi J. 2005. Metodologi Penelitian Kualitatif. Bandung. Remaja karya.

Pitana, Gde, dan Diarta, I Ketut Surya. 2009. "Pengantar Ilmu Pariwisata".Yogyakarta: CV Andi Offset

Sugiyono. 2005. Metode Penelitian Bisnis. Bandung: Alfabeta

Triatmodjo, Bambang. Januari 1999, “ Teknik Pantai". Beta Ofsfset

Undang-Undang RI Nomor 9 Tahun 1990 tentang kepariwisataan

Yulianda, F. 2007. Ekowisata Bahari Sebagai Alternatif Pemanfaatan Sumberdaya Pesisir Berbasis Konservasi. Makalah. Departemen Manajemen Sumberdaya Perairan. Fakultas Perikanan dan Ilmu Kelautan. IPB. Bogor 